\title{
The mysterious case of Aafia Siddiqui: Gothic intertextual analysis of neo-Orientalist narratives
}

\author{
Gentry, Caron Eileen.
}

\begin{tabular}{|l|l|}
\hline Date of deposit & $11 / 03 / 2016$ \\
\hline Document version & Author's accepted manuscript \\
\hline Access rights & $\begin{array}{l}\text { C The Authors 2016. This work is made available online in } \\
\text { accordance with the publisher's policies. This is the author } \\
\text { created, accepted version manuscript following peer review and } \\
\text { may differ slightly from the final published version. }\end{array}$ \\
\hline $\begin{array}{l}\text { Citation for } \\
\text { published version }\end{array}$ & $\begin{array}{l}\text { Gentry, C. E. (2016). The mysterious case of Aafia Siddiqui: } \\
\text { Gothic intertextual analysis of neo-Orientalist } \\
\text { narratives. Millennium: Journal of International Studies. }\end{array}$ \\
\hline $\begin{array}{l}\text { Link to published } \\
\text { version }\end{array}$ & https://dx.doi.org/10.1177/0305829816647120 \\
\hline
\end{tabular}

Full metadata for this item is available in St Andrews Research

Repository at: https://research-repository.st-andrews.ac.uk/

\section{St Andrews Research Repository}


Through an intertextual analysis of Gothic literature this paper will explore the narrative significance of Aafia Siddiqui, who is accused of plotting attacks on behalf of al Qaeda, to illustrate the gendered neo-Orientalist structure of the fraught cultural and political dynamics of the 'War on Terror.' States, organizations, individuals and other international actors are gendered hierarchically. ${ }^{1}$ Gender intersects with other hierarchical structurings, such as neo-Orientalism. This can be witnessed within the War on Terror (WoT) as a competition between the exceptionalized masculine US and hypermasculinized radical Islam. ${ }^{2}$ Problematically, individual lives become subsumed within this gendering. ${ }^{3}$ This article expands upon previous literature on the WoT that investigates how gender and neo-Orientalism intersect ${ }^{4}$ to demonstrate how these structures impact individual lives, specifically the life of Siddiqui.

Aafia Siddiqui was born in Pakistan and emigrated to the US in 1990 to attend university, ultimately earning her BS from MIT and a PhD from Brandeis. In 2003 her family and her were seen to have left the US for Pakistan under suspicious circumstances. Subseuqently, John Ashcroft named her as a wanted woman for her suspected

\footnotetext{
${ }^{1}$ Laura Sjoberg, Gendering Global Conflict (New York: Columbia University Press, 2013), 78-81.

${ }^{2}$ Laura J. Shepherd, 'Veiled References: Constructions of Gender in the Bush Administration Discourse on the Attacks on Afghanistan Post-9/11', International Journal of Feminist Politics 8, no. 1 (2006): 19-41, 21.

${ }^{3}$ Cynthia Enloe, Nimo's War, Emma's War: Making Feminist Sense of the War in Iraq (Berkeley: University of California Press, 2010).

${ }^{4}$ Shepherd, 'Veiled References'; Meghana Nayak, 'Orientalism and "Saving" US State Identity after 9/11', International Feminist Journal of Politics 8, no. 1 (2006): 42-61..
} 
involvement with al Qaeda. The narratives that surround Siddiqui's involvement in al Qaeda, created by the US government, media, her family, and her supporters, are situated at an intersection of gender and neo-Orientalism. ${ }^{5}$ The authors of the narratives strive to position her as an innocent 'Soccer Mom', ${ }^{6}$ the nefarious 'Lady al Qaeda', ${ }^{7}$ or the mentally confused 'Grey Lady of Bagram'. ${ }^{8}$ While all three are based upon the same facts, they fail to add up to a coherent timeline for her life between the late 1990s and 2008 , which means there is no clear evidence of who Siddiqui is or what she wanted. With the exception of what she said during her trial, her own justifications are notably absent; instead 'she' stands as an object used to serve the agenda of each narrative. She has become a mystery in the midst of the WoT.

Gothic novels, like Jane Eyre (1897) and its parallel novel Wide Sargasso Sea (1967), use mysteries as a way of subverting hierarchical paradigms. Intertextuality helps one illustrate how seemingly unrelated texts, such as socio-political narratives, are stabilized

${ }^{5}$ Shepherd, 'Veiled References'; Nayak, 'Orientalism'.

${ }^{6}$ C. Ragavan, D. Pasternak, R. Sharpe and A. Latif, 'All in the Family', U.S. News and World Report. 21 April (2003).

${ }^{7}$ Scott Shifrel, 'Pakistani Scientist "Lady al Qaeda" Sentence to 86 Years in Prison for Trying to Kill US Soldiers', New York Daily News, September 23 2010, http://www.nydailynews.com/new-york/pakistani-scientist-lady-al-qaeda-sentenced-86years-prison-kill-u-s-soldiers-article-1.442926 (November 14, 2013); Huma Yusuf, “"Lady al Qaeda:" Pakistan Reacts to Aafia Siddiqui Conviction in US Court', Christian Science Monitor. February 4 2010. http://www.csmonitor.com/World/Asia-SouthCentral/2010/0204/Lady-Al-Qaeda-Pakistan-reacts-to-Aafia-Siddiqui-conviction-in-UScourt (November 14, 2013).

${ }^{8}$ International Justice Network (IJN). 'Aafia Siddiqui: Just the Facts', http://www.justiceforaafia.org/attachments/734_Aafia_Siddiqui_-_Just_the_Facts__FINAL.pdf (November 1, 2013); Declan Walsh, 'The Mystery of Dr Aafia Siddiqui', The Guardian, November 232009. http://www.theguardian.com/world/2009/nov/24/aafia-siddiqui-al-qaida (October 8, 2013). 
by cultural knowledge of texts, such as Gothic novels. ${ }^{9}$ Gothic literature uses mystery and ambiguity to query what is held as 'known' truths, such as rationality, gender roles, and cultural ascendency. ${ }^{10}$ In particular, the classic Jane Eyre $(J E)$ and the post-colonial Wide Sargasso Sea (WSS) focus on the mystery of Rochester's 'dark secret': his non-Western wife who is hidden in the attic of his English mansion. By 'reading' Siddiqui as Rochester's (non-Western) wife from $J E$ retold in WSS as a 'lady' whose rejection of the 'superior' West leads to her imprisonment in the (colonizer's) attic and left to suffer from her (non-Western) insanity, one can see more clearly how gendered neo-Orientalist hierarchies of the WoT impact not just international events as well as individual lives. Indeed, the very construction of Siddiqui as the madwoman in Bagram becomes emblematic of the unsettled debate regarding US exceptionalism in the WoT. ${ }^{11}$

Gendered neo-Orientalism serves as the theoretical framework for the article by arguing this intersection structures the WoT. The article uses intertextual analysis as the method for paralleling the gendered and raced elements found in both JE and WSS and the

\footnotetext{
${ }^{9}$ Claudia Aradau and Jef Huysmans, 'Critical Methods in International Relations: The Politics of Techniques, Devices, and Acts', European Journal of International Relations 20, no. 3 (2014): 596-619, 605; Lene Hansen, Security as Practice: Discourse Analysis and the Bosnian War (London: Routledge, 2006); James Der Derian and Michael Shapiro, eds, International/Intertextual Relations: Postmodern Readings of World Politics (Lexington, MA: Lexington Books, 1989).

${ }^{10}$ Richard Devetak, 'The Gothic Scene of International Relations: Ghosts, Monsters, Terror and the Sublime after September 11', Review of International Studies 31, no. 4 (2005): 621-643; Carol Margaret Davison, 'Haunted House/Haunted Heroine: Female Gothic Closets in "The Yellow Wallpaper", Women's Studies 33 (2004): 47-75.

${ }^{11}$ Nayak, 'Orientalism'; Megahna Nayak and Christopher Malone, 'American Orientalism and American Exceptionalism: A Critical Rethinking of US Hegemony', International Studies Review11 no. 2 (2009): 253-276; Jasbir K. Puar, 'Abu Ghraib: Arguing against Exceptionalism', Feminist Studies (2004): 522-534.
} 
Siddiqui narratives. The second section will clarify the gendered and post-colonial elements of Gothic literature by looking at $J E$ as well as WSS. The third section will look at the three gendered neo-Orientalist Siddiqui narratives from a Gothic perspective.

Finally, the article will conclude with how Siddiqui's life has become an exemplar for the gendered structure of the WoT.

\section{Aafia Siddiqui: 'the facts'}

To help the reader better understand what is 'known' about Siddiqui, the 'facts' of her life in the US are outlined very briefly here. Siddiqui immigrated to the US in 1990 to attend university. ${ }^{12}$ During her time at MIT she became involved with Al-Kifah/Care International, a non-profit linked to both the first World Trade Center bombing and fundraising for Bosnian-Muslim violence. ${ }^{13}$ In 1995 she married her husband, an anesthesiologist from Karachi employed at Boston Brigham Women's Hospital. ${ }^{14}$ By 2002 Siddiqui had a $\mathrm{PhD}$ in neuroscience from Brandeis, two children, and was pregnant. Apparently the FBI had been watching Siddiqui since 1995 and now believed that she was smuggling conflict diamonds to finance al Qaeda. ${ }^{15}$ In March of 2003 the media broke a story that claimed Siddiqui and her family 'disappeared' overnight from Boston

\footnotetext{
12 Walsh, 'Mystery'.

${ }^{13}$ Deborah Scroggins, Wanted Women: Faith, Lies, and the War on Terror: The Lives of Ayann Ali Hirsi and Aafia Siddiqui (New York: Harper Perennial, 2012), 60-1, 84, 107. ${ }^{14}$ Walsh, 'Mystery'.

15 Katherine Ozment, 'Who's Afraid of Aafia Siddiqui?' Boston Magazine, October 2004. http://www.bostonmagazine.com/blog/2006/05/whos-afraid-of-aafia-siddiqui/ (October 8, 2013); Deborah Scroggins, 'Aafia Siddiqui', http://deborahscroggins.com/articles/vogue-magazine-article-march-2005-by-deborahscroggins/ (October 8, 2013).
} 
when the FBI began to close in believing them to be involved in an imminent attack on the DC-Baltimore area. ${ }^{16}$ More accurately the family departed Boston in late 2002 for an extended visit to Pakistan in order for Siddiqui and her husband to work on their marriage and to await the birth of their third child. ${ }^{17}$ After the birth, either Siddiqui or her husband sought the divorce and he quickly remarried. ${ }^{18}$ Newly divorced Siddiqui was introduced to Khalid Sheik Mohammad's (KSM) nephew, Ammar al Baluchi, who she married in the spring of 2003 in Pakistan and with whom she possibly went into hiding. ${ }^{19}$ The last time her mother saw Siddiqui and her children was as they got into a taxi in Karachi for a trip to Islamabad in early March 2003. ${ }^{20}$

She resurfaced with her eldest son on July 17, 2008 in Ghanzi, Afghanistan. The US's official capture story is that Siddiqui and her son were arrested by Ghanzi police, who believed she might be a suicide bomber. ${ }^{21}$ US Army and FBI agents were called to interview her. ${ }^{22}$ She was behind a curtain when the US personnel entered the room and

\footnotetext{
${ }^{16}$ Ragavan et al., 'All in the Family'.

17 Ozment, 'Who's'.

${ }^{18}$ IJN, 'Aafia'; Walsh 'Mystery'; Ozment, 'Who's'.

${ }^{19}$ Scroggins, Wanted, 245; Fisk, 'Mysterious'; Adnan Firoze, 2012, 'The Shady Story of Dr Aafia Siddiqui', March 4 2012. http://weeklypresspakistan.com/2012/03/1652 (November 1, 2013).

${ }^{20}$ Firoze, 'Shady'; Scroggins, 'Aafia'; Ozment, 'Who’s'; L. Thomas Kucharski, 'Forensic Psychological Evaluation of Aafia Siddiqui', Defendant Exhibit DX 1, Aafia Siddiqui Federal Trial 2009. http://intelfiles.egoplex.com/2009-07-01-Siddiqui-psychreport.pdf (November 1, 2013).

${ }^{21}$ Julianne von Mittelstaedt, 'America's Most Wanted: The Most Dangerous Woman in the World', Der Spiegel. 27 November 2008.

http://www.spiegel.de/international/world/america-s-most-wanted-the-most-dangerouswoman-in-the-world-a-593195.html. (July 2, 2014).

${ }^{22}$ Walsh, 'Mystery'; C. J. Hughes, 'Outbursts and Ejections in Afghan Shooting Trial', The New York Times. January 262010. www.nytimes.com/2010/01/26/nyregion/26siddiqui.html (November 1, 2013).
} 
laid down their guns, as is custom in Afghanistan. Siddiqui managed to grab one of the guns and shot at but missed the US personnel. ${ }^{23}$ She was then shot twice in the abdomen, operated upon and held at Bagram for two weeks, and flown to the US for trial. ${ }^{24}$

Siddiqui was tried in New York in 2010 on assault and attempted murder charges (no terrorism charges) and convicted to 86 years, which she is serving at Federal Medical Center (FMC) Carswell. ${ }^{25}$

\section{Contrary narratives: gendered neo-orientalism}

The aim of this paper is to illustrate how gender hierarchies that generate international structures are at work within the WoT and impact individual lives, recognizing Siddiqui as an exemplar. Gender does not, however, work on its own but intersects with identifiers like neo-Orientalism. ${ }^{26}$ This section will look at previous literature that illustrates gendered neo-Orientalist structures in the WoT.

The WoT has already been labeled a 'fictional' narrative constructed by the US government in order to compel the US public to accept the necessary policy

\footnotetext{
${ }^{23}$ Walsh, 'Mystery'; Hughes, 'Outbursts'; Marc Ambinder, 'A Terrorist Tried in Federal Court: The Case of Aafia Siddiqui', The Atlantic, February 112010.

http://www.theatlantic.com/politics/archive/2010/02/a-terrorist-tried-in-federal-court-thecase-of-aafia-siddiqui/35793/ (November 1, 2013).

${ }^{24}$ Walsh, 'Mystery'.

${ }^{25}$ FBI, 'Aafia Siddiqui Sentenced in Manhattan Federal Court to 86 Years for Attempting to Murder U.S. Nationals in Afghanistan and Six Additional Crimes', September 23 2010. http://www.fbi.gov/newyork/press-releases/2010/nyfo092310.htm (October 13, 2013).

${ }^{26}$ See author 2015; 2011.
} 
prescriptions. ${ }^{27}$ It is not that the events that led to the creation of the WoT, mainly the attacks of 9/11, were fictional but that the all-consuming threat of radical Islam, al Qaeda, and the Taliban to the US was overstated. ${ }^{28}$ All crises are narrated to form boundaries between self and other and the boundaries created by the WoT "cut across international and domestic lines". ${ }^{29}$ Critical scholars within IR and Terrorism Studies find that these self/other boundaries are reliant upon a particular version of gendered neo-Orientalism, one that positions America as the world's savior above the underfunctioning Muslim world..$^{30}$

“"Freedom', 'democracy,' ... 'justice', [and] 'terrorism' now functio[n]” as the "primary” terms "for the central narratives" of the terrorism threat. ${ }^{31}$ This establishes a binary between the progressive US (as identified in freedom, democracy, and justice) against the anti-progressive radical Islamist threat. The stabilization and consolidation of US identity was dependent upon a narrative of exceptionalism, the "commitment to a providential mission to transform the rest of the world in the image of the United States," 32 to combat

\footnotetext{
27 Ty Solomon “'I Wasn’t Angry, because I Couldn’t Believe It Was Happening:” Affect and Discourse in Responses to 9/11', Review of International Studies 38, no. 4 (2012): 907-928, 910; Richard D. Jackson, Writing the War on Terrorism: Language, Politics, and Counter-Terrorism (Manchester: Manchester University Press, 2005).

${ }^{28}$ Richard D. Jackson, 'Unknown Knowns: The Subjugated Knowledge of Terrorism Studies', Critical Studies on Terrorism 5, no. 1 (2012): 11-29; Richard D Jackson, 'Constructing Enemies: "Islamic Terrorism" in Political and Academic Discourse', Government and Opposition 42, no. 3 (2007): 394-426; Nayak, 'Orientalism', 43.

${ }^{29}$ Stuart Croft, Culture, Crisis, and America's War on Terror (Cambridge: Cambridge University Press, 2006), 8.

${ }^{30}$ Nayak and Malone, 'American Orientalism', 245.

31 Jackson, 'Constructing Enemies', 394.

${ }^{32}$ Nayak and Malone, 'American Orientalism', 260.
} 
the perceived threat from (radical) Islam. ${ }^{33}$ This was heavily gendered: the Bush administration deployed a "valorized" image of US masculinity as white and heteronormative, which was identified against the threat of radical Islamist enemy. ${ }^{34}$

While Edward Said ${ }^{35}$ is the first to critique Orientalism's discursive binary, the neoOrientalism that emerges around the WoT is related to both Huntington's Clash of Civilizations $^{36}$ and the new barbarism thesis, "where violence is seen as deeply rooted in local" Islamic "cultures". ${ }^{37}$ Where once Orientalists used to argue "that Orthodox Islam and weak societies promoted political quietism," meaning "Islamic 'submission' favored fatalism, a lack of critique, [and] despotism", ${ }^{38}$ Orientalists were forced to change their perspectives after the Iranian Revolution. Neo-Orientalists ${ }^{39}$ believe that Islam is atavistic, resistant to progress, brutal, and violent and Muslims' allegiance to sharia law means the liberal necessity of a "contract between society and state" cannot be formed. ${ }^{40}$ More particularly, neo-Orientalism differentiates between the rational Western counterterrorist and "Islamic terrorists" who are “"crazy madmen' acting under the influence of

\footnotetext{
${ }^{33}$ Nayak, 'Orientalism', 45.

${ }^{34}$ Shepherd, 'Veiled References', 23.

${ }^{35}$ Edward Said, Orientalism (London: Vintage, 1978).

${ }^{36}$ Nayak and Malone, 'American Orientalism', 256.

${ }^{37}$ Dag Tuastad, 'Neo-Orientalism and the New Barbarism Thesis: Aspects of Symbolic Violence in the Middle East Conflict(s)', Third World Quarterly 24 (2003): 591-599, 595.

${ }^{38}$ Ibid., 594

${ }^{39}$ Tuastad (2003: 594-5) specifies Daniel Pipe, Patricia Crone, Robert Kaplan, and John Hall.

${ }^{40}$ Ibid., 594-5.
} 
mental disorders and deprived of any rational logic related to social, political, or religious conditions". ${ }^{41}$

Neo-Orientalism is, therefore, a concept that has deeply gendered implications.

Rationality is a masculinized concept related to the public sphere functioning of the logical male..$^{42}$ Thus, the assumed rationality of the enlightened West and its activities are masculinized, or legitimized, whereas the assumed irrationality of Islam is delegitimized. ${ }^{43}$ For instance, men are presented as "Irrational Barbarians" who, according to President Bush, "slit the throats of women". ${ }^{44}$ Muslim men then are a threat to everyone and Muslim women are submissive and veiled ${ }^{45}$ and in need of saving in the mode of Gayatri Spivak's ${ }^{46}$ "white men saving brown women from brown men" ${ }^{47}$ The 'oppression' of Muslim women became the "categorical proof of Islamic terror" upon which the US could project its hypermasculinist protector image against and above the "dehumanized and demonized" Muslim men. ${ }^{48}$

${ }^{41}$ Christina Hellmich, 'Creating the Ideology of al Qaeda: From Hypocrites to SalafiJihadists', Studies in Conflict and Terrorism 31, no. 2 (2008): 111-124, 113.

${ }^{42}$ Carol Pateman, "“The Disorder of Women:” Women, Love, and the Sense of Justice', Ethics 91, no. 1 (1980): 20-34, 26.

${ }^{43}$ author and coauthor 2011.

${ }^{44}$ Shepherd, 'Veiled References', 25.

${ }^{45}$ Shepherd, 'Veiled References', 26; Jeffrey L. Decker, 'Terrorism (Un)veiled: Frantz Fanon and the Women of Algiers', Cultural Critique 17 (1990): 177-195.

${ }^{46}$ Gaytrai Chakravorty Spivak, 'Can the Subaltern Speak?' In Marxism and the Interpretation of Culture, ed Cary Nelson and Larry Grossberg (Urbana: University of Illinois Press, 1988), 271-313, 93.

${ }^{47}$ See also Miriam Cooke, 'Saving Brown Women', Signs: Journal of Women in Culture and Society 28, no. 1 (2002): 468-470.

${ }^{48}$ Nayak, 'Orientalism', 49-50. 
The Siddiqui narratives are thus situated within gendered neo-Orientalism, which the authors of the narratives use to gain traction amongst their audience. Whether that is achieved is not necessarily the point of this paper, instead, what is important is how gendered neo-Orientalism is constantly manufactured, reifying the hierarchical structuring between the West, particularly the US, against a gendered Muslim other and how Siddiqui's life becomes an exemplar of this tension. The interior structure of the WoT rests on gendered neo-Orientalism: of the masculine competition of US exceptionalism against a Muslim other who is feminized (as irrational and developmentally stunted) and hypermasculinized (as demonized and dehumanized) in equal measure. This interior structure can be read alongside the Gothic logics of gender and post-colonialism.

\section{Intertextual readings: narratives as texts}

IR understandings of intertextuality are owed to Roland Barthes' idea of "intertext... as 'multidimensional space in which a variety of writings, none of them original, blend and crash". ${ }^{49}$ Furthermore, Barthes argued that "things come to have meanings by virtue of their being a part of a culture". ${ }^{50}$ As such, this article argues that the Siddiqui narratives

\footnotetext{
${ }^{49}$ Donna U. Gregory, 'Foreword.' In International/Intertextual Relations: Postmodern Readings of World Politics. James Der Derian and Michael Shapiro, eds. (Lexington, MA: Lexington Books, 1989): xiii-xxi, xix.

${ }^{50}$ as quoted in James Der Derian, James, 'The Boundaries of Knowledge and Power in International Relations.' In International/Intertextual Relations: Postmodern Readings of World Politics. James Der Derian and Michael Shapiro, eds. (Lexington, MA: Lexington Books, 1989): 3-10, 6.
} 
are texts that 'blend and crash' with the texts of $J E$ and WSS in ways that collapse and subsume Siddiqui's personhood within gendered neo-Orientalist structures.

Where Kristeva uses intertextuality to "demonstrat[e] the inherent instability or contingency of meaning", ${ }^{51}$ Lene Hansen's understanding fixes identity. ${ }^{52}$ For instance, texts are "simultaneously unique and united: each ... weaves a series of differentiations and juxtapositions. ${ }^{" 53}$ One is able to look at how the texts on Siddiqui fix neo-Orientalist assumptions of US superiority/Muslim inferiority whilst simultaneously making different arguments. The West's author-ity over the Orient is a discursive narrative. ${ }^{54}$ Even though the Siddiqui narratives disagree because the different authors of "stories present different agendas for action" ${ }^{\prime 5}$ each is reliant upon gendered neo-Orientalism. The dissimilar narratives reify or refute particular structural hierarchies and thus narratives begin at varying if not opposing starting points. ${ }^{56}$

Furthermore, Michael Shapiro argues that the value of texts "is...not to be discerned in their correspondence with something, but rather in the economics of possible

\footnotetext{
${ }^{51}$ Ibid., 606.

${ }^{52}$ Hansen, Security as Practice, 54.

53 Ibid., 49.

${ }^{54}$ Said, Orientalism, 7.

${ }^{55}$ Erik Ringmar, 'Inter-Texual Relations The Quarrel Over the Iraq War as a Conflict between Narrative Types', Cooperation and Conflict 41, no. 4 (2006): 403-421, 404.

${ }^{56}$ Charlotte Epstein, 'Constructivism or the Eternal Return of Universals in International Relations. Why Returning to Language is Vital to Prolonging the Owl's Flight', European Journal of International Relations 19, no. 3(2013): 499-519, 508; Hidemi Suganami, 'Narrative Explanation and International Relations: Back to Basics', Millennium-Journal of International Studies 37, no. 2 (2008): 327-356, 342.
} 
representations within which they participate." 57 Thus, beyond the framing of Siddiqui within neo-Orientalism, this researcher has observed how the Siddiqui narratives tract with the gendered and post-colonial gothic elements of $J E$ and WSS and the economies of representing her as different characters from both novels. Intertextuality "function[s] as an inscription device that draws together a series of things/documents and orders them in particular ways" ${ }^{58}$ It "implies a particular understanding of what texts are and how they generate meaning" ${ }^{59}$ By drawing upon Gothic literary analysis that focuses upon how $J E$ upends gender hierarchies and then how WSS brings this challenge to colonialism, this article acts as an 'inscription device' to read Siddiqui through JE and WSS.

\section{Gothic logics and power structures}

Richard Devetak argues that much of President Bush's “discourse of national security" after September $11^{\text {th }}$ "assumes many of the predicates of gothic narratives," including "death, dread, [and] darkness" to "generate" social fear and anxiety. ${ }^{60}$ Such unease may be dismissed due to Gothic literature's ties to ghost stories, yet Gothic novels use it to reflect contemporaneous socio-cultural tensions. ${ }^{61}$ Devetak stays focused upon larger tensions, such as the WoT, through his intertextuality of Poe's The Fall of the House of Usher and Shelley's Frankenstein. My argument attempts to find the connections

${ }^{57}$ Michael Shapiro, 'Textualizing Global Politics.' In International/Intertextual Relations: Postmodern Readings of World Politics. James Der Derian and Michael Shapiro, eds. (Lexington, MA: Lexington Books, 1989): 11-24, 13.

58 Aradau and Huysmans, 'Critical Methods', 605

${ }^{59}$ Ibid, 605.

${ }^{60}$ Devetak, 'The Gothic Scene', 621, 630.

${ }^{61}$ Ibid, 623. 
between the individual and the structural, using gender and neo-Orientalism to do so. The choice here to focus upon $J E$, a well-regarded classic Gothic novel, and subsequently WSS is because their own interior logics are reflective of gender and post-colonial hierarchies that are eerily similar to the logics in the Siddiqui narratives.

Drawing upon Gothic literary scholars helps me to identify Gothic literature's seeming determination to undo gendered ideals by questioning the naturalness of men's heroism and women's moral weakness. ${ }^{62}$ Another Gothic element is in the reliance upon supernatural happenings — 'the dark secret' — that end up having an explanation rooted in the material world. ${ }^{63}$ These 'secrets' were used to signify the uneasy transition from a religious-based social order to modern rationalism. ${ }^{64}$ Both gender and secrets come to the fore in $J E$ and WSS as ways of questioning socio-political structures and are important in posing doubt towards the 'war's' neo-Orientalist constructions of the Siddiqui narratives.

\section{Gendered Gothic: Jane Eyre}

Caesarea Abartis highlights the ambiguities of the gothic genre through her brief explanation of $J E$ :

Jane is an impoverished orphan who is neglected and abused by her aunt. Jane eventually becomes a governess to a child at Thornfield Hall where the master is

\footnotetext{
${ }^{62}$ Davison, 'Haunted House'; see Beverley Skeggs, Formations of Class and Gender: Becoming Respectable (London: Sage, 1997), 3.

${ }^{63}$ Robert D. Hume, 'Gothic versus Romantic: A Revaluation of the Gothic Novel', Publications by the Modern Language Association of America 84, no. 2 (1969): 282-290, 287.

${ }^{64}$ Hume, 'Gothic'.
} 
Edward Rochester, a moody, brusque, older man. She almost marries Rochester before the secret of the third floor is made known: Rochester has a wifedemented and bestial. Ultimately, of course, Jane and Rochester marry, but only after his first wife has died in the fire which destroys the manor and cripples and blinds Rochester in a poetic punishment for his bigamous desires. ${ }^{65}$

These are Gothic elements that feed into disquieting oxymorons: forcefully naïve female characters, threatening protective male characters, and supernatural realities that confront and engage the reader.

Gothic novels subvert gender-ideal types to make these intrusions ${ }^{66}$ If patriarchy's construction of the public sphere insists that middle- and upper-class men alone are in possession of rationality and thus the only people capable of exercising justice, ${ }^{67}$ Gothic novels no longer afford the reader with such certainty. The heroine may be naïve and the male protagonist strong and bold, but their other character traits upend patriarchal moral ordering, creating ambiguity. In Gothic novels heroic masculinity is complicated as male protagonists are alternatively helpful and strong or troubled and violent. ${ }^{68} \mathrm{Jane}$ describes Rochester as “mood[y] [and] hars[h]" with a "fault[y]...morality". ${ }^{69}$ Rochester's

\footnotetext{
${ }^{65}$ Ceseara Abartis, 'The Ugly-Pretty, Dull-Bright, Weak-Strong Girl in the Gothic Mansion', Journal of Popular Culture 13, no. 2 (1979): 257-263, 258.

${ }^{66}$ Ibid; Hume, 'Gothic'; Davison, 'Haunted House'.

${ }^{67}$ Amanda Third, 'Imprisonment and Excessive Femininity: Reading Ulrike Meinhof's Brain', Parallax 16, no. 4 (2010): 83-100, 84-5; Jean Bethke Elshtain, Private Man, Public Woman: Women in Social and Political Thought (Princeton: Princeton University Press, 1981); Pateman, 'Disorder', 24-25.

${ }^{68}$ Hume, 'Gothic', 287.

${ }^{69}$ Charlotte Brontë, Jane Eyre (London: Service and Paton, 1897 [1847]), 97.
} 
masculinity is secured by his demeanor but undermined by his morality. ${ }^{70}$ In many Gothic novels the female characters are trapped by a patriarchal society, but the (good) woman still becomes the hero-ine: Jane does what is right—fleeing Rochester's desirewithin her quiet, plain femininity. ${ }^{71}$ The reader is able to trust "plain" Jane's moral challenge of both "moody" Rochester and the patriarchy only because her femininity is untainted.

The 'dark secret': Wide Sargasso Sea

In American Gothic literature unease also stems from the threat of the 'other' from a lesscivilized locale. ${ }^{72}$. American Gothic demonstrates that "darkness and grotesque" exist in society and erode notions of exceptionalism. ${ }^{73}$ The South with its racist legacies is often the setting because it reflects a particular "otherness," granting a separation from which "everything...the nation wants to disassociate itself" ${ }^{74}$ Colonial protectorates served a similar purpose, playing on the dark legacies hidden in Manifest Destiny. A good example of this is Francis Ford Coppola's post-colonial exploration of the Vietnam War in Apocalypse Now (1979), which is, of course, a borrowed plotline from Joseph Conrad's criticism of European colonization, Heart of Darkness (1899). It is not difficult then to see Afghanistan today as a new colonial frontier for the US and the WoT as a neoimperialist project with not-so hidden darknesses.

\footnotetext{
${ }^{70}$ Abartis, 'Ugly-Pretty', 258.

${ }^{71}$ Brontë, Jane Eyre, 169; see Davison, 'Haunted House'.

72 Teresa A. Goddu, Gothic American: Narrative, History, and Nation. (New York: Columbia University Press, 1997), 4.

${ }^{73}$ Ibid., 4.

${ }^{74}$ Goddu, Gothic American, 4.
} 
Colonization and imperialism are rooted in (white) Western superiority as premised on progress, rationality, and morality—all characteristics colonized peoples supposedly had no access to. ${ }^{75}$ The supernatural elements in Gothic fiction introduce doubt towards this bias by probing moral ambiguities. ${ }^{76}$ To that end, many Gothic novels employ a 'dark secret,' which is often the cause of perceived supernatural events that have a logical explanation behind them. ${ }^{77}$ Returning to $J E$, the reader's suspicion that Thornfield Hall was haunted was falsified when Rochester's wife was discovered. Yet, the dark secret is bigger than just one person, one occurrence, or one turn in the plotline. I argue that the dark secret is emblematic of larger social ills, such as gender or colonialism.

WSS rewrites Rochester's wife, Antoinette Cosway, as a wealthy Creole woman who no longer has a place in post-slavery Jamaica under British imperial rule. Antoinette describes herself as caught between the English-ness her mother aspires to ${ }^{78}$ and her family's previous history with slave-trading. ${ }^{79}$ Rochester is torn between desire and disregard for her: "Creole of pure English descent she may be" but her "long, sad, dark alien eyes" "are not English or European" ${ }^{80}$ Her 'alienness' is also found in her

\footnotetext{
75 See Albert Memmi, The Colonizer and the Colonized (London: Routledge, 2013), 545, 82-3, 180-1; Beverly Skeggs, Formations of Class and Gender: Becoming Respectable (London: Sage, 1997), 42.

${ }^{76}$ Devetak, 'The Gothic Scene', 623; Hume, 'Gothic,' 287.

77 Abartis, 'Ugly-Pretty', 261.

${ }^{78}$ Jean Rhys, Wide Sargasso Sea, edited by Angela Smith (London: Penguin Classics, 1997 [1966]), 18.

${ }^{79}$ Ibid., 64.

${ }^{80}$ Ibid., 40.
} 
acceptance of obeah, 'witchcraft' imported from Africa through the slave trade. Several times she is described by others as a "zombi" or zombie. ${ }^{81}$

When Antoinette professes her disbelief in God, Rochester tries to bring her 'back' into the Western/Christian fold by suddenly re-christening her Bertha. ${ }^{82}$ Yet it is too late, this is the night that Antoinette breaks with reality; subsequently Rochester secretly brings her to England to be confined in Thornfield's attic. Antoinette is a colonized person who has failed to live up to the civilizational and gendered expectations of Victorian England and thus must be contained. The deeper secret is not necessarily Antoinette's captivity but the legacy of gendered colonial imperialism.

\section{Contained: gendered neo-Orientalist narratives}

All narratives typically rely on the same facts but narrate them differently as a way of setting an agenda that benefits the story-teller/author. ${ }^{83}$ In this way, Siddiqui's 'life-story' is a manipulation by those invested in her life for their benefit. Nonetheless all three narratives, innocent Soccer Mom, nefarious Lady al Qaeda, and mysterious Grey Lady, are reliant upon neo-Orientalism to find coherency within the American audience. ${ }^{84}$ The US government is invested in her guilt and in the fight against terror and "news media generally take their cue from national governments...only rarely do they contest or

${ }^{81}$ Ibid., 14-5, 62, 67.

82 Ibid., 86.

${ }^{83}$ Ringmar, 'Inter-textual', 407.

${ }^{84}$ See John L. Esposito and Ibrahim Kalin, eds, Islamophobia: The Challenge of Pluralism in the $21^{\text {st }}$ Century (Oxford: Oxford University Press, 2011). 
modify" the government's narratives. ${ }^{85}$ Thus, some American media sources ${ }^{86}$ are the primary authors of the Lady al Qaeda narrative - the only narrative that asserts Siddiqui's collaboration with al Qaeda. While a few Pakistani media sources ${ }^{87}$ present her as guilty in gendered ways, other Western sources claim she has become a cultural icon of innocence in Pakistan. ${ }^{88}$

The two different innocent narratives espoused by Siddiqui's family and supporters counter the government-media nexus. In particular, her brother and sister are invested in proving her innocence. They are both Pakistani citizens who have resided in the US ${ }^{89}$ and their family's credibility as 'good Muslims ${ }^{90}$ rests on its disassociation from radical Islamism. The Grey Lady narrative emerged alongside the Free Aafia movement, when her family was joined by academics, ${ }^{91}$ journalists, ${ }^{92}$ and human rights activists; ${ }^{93}$ each of

\footnotetext{
${ }^{85}$ Michael V. Bhatia, 'Fighting Words: Naming Terrorists, Bandits, Rebels and Other Violent Actors', Third World Quarterly 26, no. 1 (2005): 5-22, 10.

${ }^{86}$ Ambinder, 'A Terrorist'; Hughes, 'Outbursts'; Scroggins, 'Aafia'; Ozment, 'Who's'; Ragavan et al., 'All in the Family'.

${ }^{87}$ Hamid Manzoor, 'Aafia Siddiqui Mystery: Extracting the Hard Facts', http://archives.dailytimes.com.pk/national/10-Jul-2010/aafia-siddiqui-mystery-extractingthe-hard-facts (1 November 2013); Aroosa Masroor, 'Dr Aafia Siddiqui's Husband Breaks His Silence After Six Years', The News International 18 February 2009, http://www.thenews.com.pk/TodaysPrintDetail.aspx? ID=20404\&Cat=13\&dt=2/18/2009 (1 November 2013).

${ }^{88}$ Fisk, 'Mysterious'; Yusuf, 'Lady al Qaeda'.

${ }^{89}$ Walsh, 'Mystery'.

${ }^{90}$ See Yvonne Yazbeck Haddad and Nazir Nader Harb, 'Post-9/11: Making Islam an American Religion', Religions 5, no. 2 (2014): 477-501.

91 Aysha Shafiq, 'The War on Terror and the Enforced Disappearances in Pakistan', Human Rights Review 14, no 4 (2013): 387-404.

92 Victoria Catherine Brittain, 'A Case History of State Terrorism: The Siddiqui Case', Islamic World Peace Forum. http://en.iwpeace.com/articles/4081 (October 8, 2013); Yvonne Ridley, 'Hoover, the FBI, and Aafia Siddiqui', http://yvonneridley.org/analysisand-opinion/hoover-the-fbi-and-aafia-siddiqui// (February 12, 2015).
} 
these actors position Siddiqui as an example of US injustice in the torture and illegal detainment debate. The authors rely heavily on social media to disseminate information about Siddiqui. Social media platforms put them at a disadvantage against the government and mainstream media because the audience's evaluation of these sources is dependent upon personal conceptualizations of credibility and legitimacy. ${ }^{94}$

The soccer mom

The first innocence narrative conflates the expectations of the American 'soccer mom' with the neo-Orientalist assumptions of Muslim womanhood. The concept of the soccer mom emerged in the 1996 American Presidential election as the group that could swing the vote. ${ }^{95}$ 'Soccer moms' are well-educated white women in their 20s to 40 s who have careers and children, married to professionals, drive a sports-utility vehicle, own a home in the suburbs, and attend church regularly. ${ }^{96}$ When Siddiqui came under suspicion and then 'disappeared' in 2003 , her family told the US press that she was simply a "woman with children, wearing a hijab, [and] driving a Volvo". ${ }^{97}$ (In disparagement of this the

${ }^{93}$ Asim Qureshi, 'Researching Rendition and Torture in the War on Terror: Lessons from a Human Rights Organization', Critical Studies on Terrorism 2, no. 2 (2009): 365-376; cageprisoners.com.

${ }^{94}$ David Westerman, Patric R. Spence, and Brandon Van Der Heide, 'Social Media as Information Source: Recency of Updates and Credibility of Information', Journal of Computer-Mediated Communication 19, no. 2 (2014): 171-183; see also Minjeong Kang, 'Measuring Social Media Credibility: A Study on a Measure of Blog Credibility,' Institute for Public Relations, 2010), 5.

${ }^{95}$ Cynthia Starnes, 'Reflections on Betty Crocker, Soccer Moms, and Divorce: A Message from Detergent Manufacturers', Wisconsin Law Review (1997): 285-294, 286. ${ }^{96}$ Ibid, 286.

${ }^{97}$ Ragavan et al., 'All in the Family'. 
New York Post ran the headline "Al Qaeda Mom" ${ }^{98}$ ). While neither Jane nor Siddiqui perfectly fit the mold of the American soccer mom, elements of it linger within both of their stories. A lazy reading of Jane would align her as a soccer mom of the Victorian era: a well-educated (for a woman) governess, combining career and children (even if they aren't her own). A deeper reading would trouble this assumption of belonging. Jane faced significant rejection and abuse as an orphan. Her place in the Thornfield household was dependent upon either her employment by or her romantic relationship with Rochester, both of which implode when Antoinette is discovered.

It also took some time for Siddiqui to arrive at this ill-fitting American-dream lifestyle and the arrival at it is only 'known' through what her family and friends have asserted. A Boston magazine article very carefully highlights her soccer mom qualities, doubting this woman could have smuggled African conflict diamonds for al Qaeda. Siddiqui "is a 29year-old mother of two, consumed, like other Boston moms who volunteer or work outside the home, with the minutiae of everyday life". ${ }^{99}$ She is genteel as "a deeply religious woman, she picks up Korans from a local mosque and distributes them to inmates in area prisons". ${ }^{100}$ The article secures Siddiqui's upper-middle-class status: she "hosts play groups in her apartment on the 20th floor of the Back Bay Manor in Roxbury;" takes care of her sister's children; and Siddiqui “does the grocery shopping

\footnotetext{
${ }^{98}$ Walsh, 'Mystery'.

${ }^{99}$ Ozment, 'Who's'.

${ }^{100}$ Ibid.
} 
and prepares meals for her children and [doctor] husband". ${ }^{101}$ In other words, Siddiqui was not terribly different than any other Greater Boston soccer mom.

Yet, she was just different enough to warrant some defensiveness. The imam at her mosque stated in an interview: "She was an American girl. Put that down: Aafia Siddiqui was an American girl". ${ }^{102}$ Friends and peers describe her as "academic" yet "faith" driven, "passion[ate] about Islam," and "kind." 103 This positions Siddiqui as bound to her faith, in effect veiling her. Veiling holds that faithful Muslim women are oppressed ${ }^{104}$ and Siddiqui's family used this to defend her innocence and establish her husband as the al Qaeda operative. ${ }^{105}$ Her sister stated that he is a "wifebeater" and "marrying him was Aafia's biggest mistake". ${ }^{106}$ Thus disparate conceptualizations of Siddiqui cohere: she is the ideal American woman, i.e. a woman with both career and children, but one held back by her less-progressive, sinister, and subversive radical Islamic husband. ${ }^{107}$ The Soccer Mom narrative falls apart, however, when Siddiqui is not seen between 2003 and 2008.

\section{Lady al Qaeda}

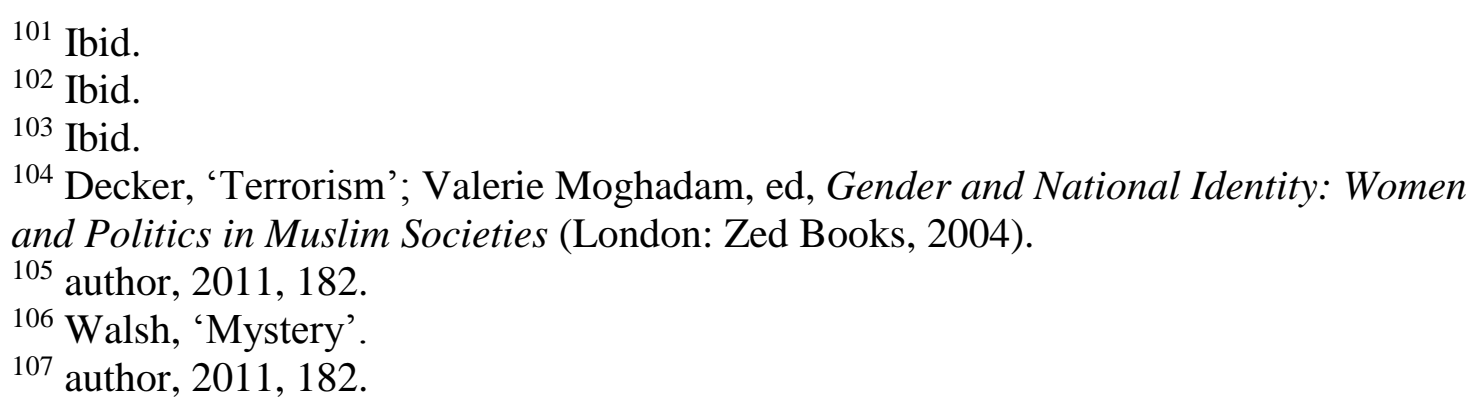


In 2004 John Ashcroft "listed [Siddiqui] among the seven most wanted Al-Qaeda fugitives". ${ }^{108}$ The 'Lady al Qaeda' moniker emerged in the media, from sources as varied as New York Daily News, The Christian Science Monitor, and Al Jazeera, and finds resonance with its audience through gendered neo-Orientalism. ${ }^{109}$ The Lady al Qaeda narrative is used to present Siddiqui as someone who has betrayed American exceptionalism: how does an audience make sense of a woman who 'looks' like a soccer mom but that the government and media insist has been helping al Qaeda since the late1990s?

As neo-Orientalism post-9/11 is dependent upon the 'new barbarism' thesis, the Lady al Qaeda narrative is premised upon prior family ties to a particular Islamic 'tribe.' Siddiqui's family were Deobandis, a form of political Islam that had supported the mujahedeen in Afghanistan and then the Taliban. ${ }^{110}$ This is seen as a radicalizing context for Siddiqui, which corresponds with statements from Siddiqui's ex-husband. ${ }^{111}$ From the start of their marriage, Siddiqui had "a more fiery character than he wished. 'She was so pumped up about jihad" " he told a Guardian reporter. ${ }^{12}$ To a Pakistani journalist, he said, "She got hysterical fits when she became angry and would physically attack me..."

108 Janine Di Giovanni, 'Aafia Siddiqui: The Woman ISIS Wanted to Trade for Foley, Then Sotloff,' Newsweek, http://www.newsweek.com/2014/09/26/aafia-siddiqui-womanisis-wanted-trade-foley-then-sotloff-270830.html (February 12, 2015).

${ }^{109}$ Shifrel, 'Pakistani'; Yusuf, 'Lady al Qaeda'; Manzoor, 'Aafia'; Masroor, 'Dr Aafia's'. ${ }^{110}$ Scroggins, Wanted Women, 6.

${ }^{111}$ Ibid, 24, 46, 70.

${ }^{112}$ Walsh, 'The Mystery'. 
and that "he found her opinion toward Jihad to be of an extreme nature that...made him uncomfortable". 113

In order to explain her disappearance between 2003 and 2008, the audience is meant to believe that Siddiqui marries into one of the most politicized families in Pakistan after her divorce. Divorce lends credibility to Siddiquils guilt: in 2002, "Aafia was a scorned and lonely creature, a divorced woman in Pakistan". ${ }^{114}$ Divorce coheres with some of the more gendered rationale for women's involvement in terrorism and political violence: that women become involved in terrorism when they have lost their social standing and respect in Islamic societies. ${ }^{115}$ Thus, when the 'scorned' Siddiqui is introduced to al Baluchi she marries him. Supposedly al Baluchi involved Siddiqui in the Baltimore-DC attacks. ${ }^{116}$ When she goes underground with him in 2003, her status as Lady al Qaeda is sealed. $^{117}$

She was found with "various sealed canisters of chemicals and gels" as well as the “Anarchist Arsenal" and a list of US targets. ${ }^{118} \mathrm{Her} \mathrm{PhD}$ in neuroscience (focusing on learning disabilities) is misrepresented as "neurobiology"119 and was implicated as of

\footnotetext{
${ }^{113}$ Voice of Baltistan, 'Dr Aafia Siddiqui's Husband Breaks His Silence After Six Years,' http://baltistani.com/dr-aafia-siddiquis-husband-breaks-his-silence-after-sixyears/ (Novembr 16, 2012) ${ }^{114}$ Scroggins, Wanted Women, 218.

${ }^{115}$ Mia Bloom, Bombshell: The Many Faces of Women Terrorists (New York: C. Hurst and Publishers, 2011), 31, 135; Robert Pape, Dying to Win: The Strategic Logic of Suicide Terrorism (New York: Random House, 2005), 209.

116 Scroggins, Wanted Women, 245.

117 Scroggins, Wanted Women, 245; Firoze, 'Shady'; Fisk, 'Mysterious'.

${ }^{118}$ Ambinder, 'A Terrorist'.

${ }^{119}$ Ibid.
} 
intrinsic value to planning future al Qaeda attacks. ${ }^{120}$ And when she opens fire on US personnel in Ghanzi, she is the embodiment of Lady al Qaeda:

[Siddiqui] was standing there, pointing the officer's gun at his head....She fired twice, shouting 'Get the fuck out of here!' and 'Allahu Akbar!' Nobody was hit. After the translator wrestled with the woman, the second soldier drew his pistol and fired...She went down, still kicking and shooting that she wanted 'to kill Americans.' Then she passed out. ${ }^{121}$

According to a witness, "Captain Robert Snyder, [Siddiqui was] 'a vision of hatred...shooting at us. Shooting at me". ${ }^{122}$ She is Antoinette, who, in a fit of 'madness,' attacks Rochester, rejecting 'Bertha'. ${ }^{123}$ Through this Siddiqui text, the audience is presented with a similarly colonized woman who has already rejected the "better choice'-her promising American future.

\section{The Grey Lady appears}

Once Siddiqui defied capture, the innocent Soccer Mom narrative no longer has any validity, as it would appear that Siddiqui was indeed underground for those five years. Instead, the Lady al Qaeda narrative seems all the more plausible. Thus, a new innocence

\footnotetext{
${ }^{120}$ Hughes, 'Outbursts'; Walsh, 'The Mystery'; von Mittelstaedt, 'America's'.

${ }^{121}$ Walsh, 'Mystery'.

122 Janine Di Giovanni, 'Aafia Siddiqui: The Woman ISIS Wanted to Trade for Foley, Then Sotloff', Newsweek, 26 September 2014, http://www.newsweek.com/2014/09/26/aafia-siddiqui-woman-isis-wanted-trade-foleythen-sotloff-270830.html (February 12, 2015)

${ }^{123}$ Rhys, Wide Sargasso, 95-6.
} 
narrative has to be sought and the one that emerged was the Grey Lady of Bagram. Upon return to the US, her mental condition was fragile and each side interprets Siddiqui's mental health as evidence of her guilt or innocence.

A US-government conducted psychological evaluation of her at Carswell in 2009 suggests she has "Delusional Disorder of the Paranoid type" and that "some of her beliefs" are consistent with "radical political ideology" while other "beliefs exceed political theology". ${ }^{124}$ An otherwise well-balanced Guardian article stated "she manipulated health workers" "and three of four [mental health] experts determined she was malingering". ${ }^{125}$ (Although the Carswell psychological evaluation negates this. ${ }^{126}$ ) Further, the reporter indicated that she was "scuppering" her pre-trial hearings by interrupt[ing] the judge, rebuk[ing] her own lawyers, and [making] strident appeals...[.] ...Previously she had tried to fire her lawyers due to their Jewish background. $^{127}$

Alternatively, her defense claims Siddiqui was unfit to stand trial: "Siddiqui was 'going crazy' - prone to crying fits and hallucinations involving flying infants, dark angels, and a dog in her cell. 'She's in total psychic pain' said her lawyer". ${ }^{128}$ International Justice Network (IJN), an independent non-profit that provides legal assistance to survivors of human rights abusers, found that her "mental and physical health continues to

\footnotetext{
${ }^{124}$ Kucharski, 'Forensic', 10-11.

125 Walsh, 'Mystery'.

${ }^{126}$ Kucharski, 'Forensic', 8, 12.

127 Walsh, 'Mystery'.

${ }^{128}$ Ibid.
} 
deteriorate" from her "solitary confinement" at Carswell. ${ }^{129}$ For those who believe in her innocence, these actions indicate mental frailty due to torture. ${ }^{130}$

Still, supporters like IJN and Victoria Brittain have to contend with this vitriolic Siddiqui. When they argue Siddiqui's behavior is a result of her diminished capacity, Siddiqui 'tranforms' fully into Antoinette: she cannot be held responsible for her actions as they are due to her torture and her unstable background as a Muslim woman. It may seem strange to construct Siddiqui as a captive woman à la Antoinette but the postcolonial/neo-Orientalist parallels are there. Like Antoinette, Siddiqui is a person of color who was 'presented' with the advantages of a Western life: educational and/or economic opportunities that should have allowed her to leave behind her 'backwards' non-Western (Islamic) existence. Instead, just as Antoinette was, in the end, associated more with obeah and Jamaican culture than with being English, the Grey Lady narrative is somewhat dependent upon the idea that Siddiqui maintained stronger ties with Islam than with the (more progressive) West. Antoinette was locked away in Rochester's attic because she was guilty of noncompliance with gendered and classed expectations of her as an English wife. Thus, Siddiqui's imprisonment in Bagram for five years falls into line with Rochester's treatment of Antoinette — an attempt to deny the challenge to this superior political system and to force compliance with it.

Bagram Theater Internment Facility is the largest detention center in Afghanistan and located within US Bagram Air Base. ${ }^{131}$ Bagram, like Abu Ghraib, is known for having

${ }^{129}$ IJN, 'Aafia', 2.

${ }^{130}$ Brittain, 'A Case History'. 
tortured inmates. Free Detainees, a non-profit website dedicated to raising awareness about prisoners associated with America's WoT, described Siddiqui's imprisonment at Bagram in 2008:

Prisoner 650 is a Pakistani Muslim woman held by the American military for many years without trial in the notorious Bagram Prison in Afghanistan. Her screams have reached the ears of many ex-inmates and others who have visited the prison. They all claim that the screams still haunts [sic] them. They have labeled her the Grey Lady of Bagram jail...

According to British journalist Yvonne Ridley "her haunting sobs and piercing screams" led "male prisoners to go on hunger strike for six days in protest of her treatment". ${ }^{132}$

The Grey Lady narrative is premised on the belief that Siddiqui had been held from 2003 to 2008 at Bagram. Her advocates argue that Pakistani and US forces intercepted Siddiqui and her children on their way to the train station in March 2003. At this time, a spokesman for Pakistan's interior ministry and two unnamed US officials confirmed [her capture] in the press. Several days later, however, Pakistani and

131 Amber Hildebrandt,. 'Bagram Prison: The "Other Guanatanmo"”, CBC News, September 26 2011. http://www.cbc.ca/news/canada/bagram-prison-the-otherguantanamo-1.997544 (November 1, 2013); Ben Farmer, Philip Sherwell, and Dean Nelson, 'Afghanistan's “Guantanamo” Poses New Prison Problem for Barak Obama', The Telegraph. January 24 209. http://www.telegraph.co.uk /news/worldnews/barackobama/4332499/Afghanistans-Guantanamo-poses-new-prisonproblem-for-Barack-Obama.html (November 1, 2013); Eliza Griswold, 'Black Hole: The Other Guantanamo', New Republic. May 72007. http://www.newrepublic.com/article/black-hole-the-other-guantanamo (November 1, 2013).

${ }^{132}$ Walsh, 'Mystery'. 
American officials mysteriously backtracked, saying it was unlikely Siddiqui was in custody. ${ }^{133}$

Persistent rumors culminated in a press conference held by Ridley in Afghanistan that was meant to force the U.S. to name Prisoner 650. Lt-Col Rumi Nielson-Green, Director of Public Affairs for the region, denied that any woman, specifically Prisoner 650, was being held at Bagram in July 2008. ${ }^{134}$ The Ghanzi capture happened tens days after the press conference. Thus, the Ghanzi capture is considered to be a fabricated story supported by the claims that there is no physical evidence linking Siddiqui with the gun that shot the soldier. ${ }^{135}$

Because of these mysterious circumstances Siddiqui has become an innocent martyr in some of the Pakistani press. ${ }^{136}$ (Although some articles in the Pakistani press uphold the Lady al Qaeda narrative from a gendered perspective: to promote her guilt and her exhusband's innocence. ${ }^{137}$ ) After her conviction in 2010 the Pakistani government asked to have her repatriated from the US, referring to her as the "daughter of the nation". ${ }^{138}$ She is an international "symbol of American injustice"139 and "another example of the US government's high-handedness" towards Pakistan and Afghanistan. ${ }^{140}$ This doubt and

\footnotetext{
133 Ozment, 'Who's'; see also IJN, 'Aafia'; Qureshi, 'Researching Rendition'.

134 Ridley, 'Hoover'.

135 Brittain, 'A Case History'.

${ }^{136}$ Ibid.

${ }^{137}$ Manzoor, 'Aafia'; Masroor, 'Dr Aafia's'.

${ }^{138}$ Ridley, 'Hoover'; Fisk, 'Mysterious'.

${ }^{139}$ Fisk, 'Mysterious'.

${ }^{140}$ Shafiq, 'The War on Terror'; Yusuf, 'Lady al Qaeda'; Qureshi, 'Researching Rendition'.
} 
tension solidifies the Grey Lady narrative, exemplifying the tensions inherent in the gendered hierarchical relationship between the US and Afghanistan and Pakistan in the WoT.

Gendered neo-Orientalism, the Gothic, and Aafia Siddiqui

Neo-Orientalism orders the narratives, serving the particular agendas of the various authors of the narratives and supporting the gender hierarchy. Paralleling the gendered and post-colonial Gothic logics with the gendered neo-Orientalist elements demonstrates just how damaging this discursive structuring is as it fixes the various identities in totalizing ways: a monolithic view of the US and an essentialized view of Siddiqui. Yet, employing Gothic intertextuality has a redeeming feature as well.

Bonnie Honig explores Gothic literature's contributions towards democratic thought and practice. ${ }^{141}$ According to Honig, the Gothic heroine explores ambivalence to "discover the truth."142 This act of "detection teaches them agency," making the heroines less vulnerable to immediate and structural threats. ${ }^{143}$ Readers of Gothic novels can discover that the devices used by Gothics to heighten our sense of uncanniness... are devices that work on us everyday and that we, as democratic

${ }^{141}$ Bonnie Honig, Democracy and the Foreigner (Princeton: Princeton University Press, 2001).

142 Ibid., 118.

${ }^{143}$ Ibid., 118. 
agents, do not just have to yield to them. Instead, we have some power to explore, unmask, detect, and even expose them. ${ }^{144}$

The Free Aafia movement fills the role of a Gothic heroine-it employs the more subjective social media to explore, unmask, detect, and expose undemocratic activities. Siddiqui's advocates continue to believe in a world where human rights matter, and thus they refuse to turn a blind eye to torture and detainment. This real-life 'Gothic heroine' gives voice to "cultural contradictions" subverting American exceptionalism. ${ }^{145}$ The Free Aafia movement-as-Jane "provide us [the reader] with...a healthy caution to be wary of authorities and powers that seek to govern us". ${ }^{146}$ As such, the Free Aafia movement challenges not just America-as-the-male-protagonist but empowers citizens to rethink their complicity. Yet we can also see that Free Aafia movement has its own agenda in presenting Siddiqui in such a light—-she can only be a victim if there is an assailant.

Scripting America as a 'male protagonist' is not necessarily new, ${ }^{147}$ but it is relevant. In the WoT, America has projected a masculinity of an exceptionalized protector of women. The Bush Administration argued the war in Afghanistan would not just rid Afghanistan of the Taliban and the world of al Qaeda, but the Western forces would also liberate the veiled women. ${ }^{148}$ Yet, as Cynthia Weber rather presciently wrote, the WoT resides within

\footnotetext{
144 Ibid., 118.

${ }^{145}$ Goddu, Gothic American, 10; see also Puar, 'Abu Ghraib'.

146 Honig, Democracy, 118.

${ }^{147}$ Bonnie Mann, 'The Gender Apparatus: Torture and the National Manhood in the US "War on Terror"', Radical Philosophy 168 (2011), http://www.radicalphilosophy.com/article/the-gender-aparatus (October 8, 2013).

148 Shepherd, 'Veiled References', 25.
} 
a contradictory moral framework. ${ }^{149}$ The WoT was meant to serve as a way of exporting American democratic values. ${ }^{150}$ If the Grey Lady narrative is true the honorable and romanticized reasons for going to Afghanistan crumble. No longer can America claim liberal exceptionalism nor can it claim that it is free of gender troubles. The possibility that American soldiers tortured and secretly detained a woman on an air base - not events that happened erroneously in the heat of battle — opens the door to more shame, disquiet, and horror in a post-Abu Ghraib environment. Thus, the Grey Lady narrative connotes uneasiness towards American counterterrorism policies, including the wars in Afghanistan and Iraq as well as torture and detention, which upsets the image of an exceptional United States that the Bush and Obama administrations insist it is. ${ }^{151}$

\section{Thornfield's attic/Bagram Prison}

Gothic logics are used to point out ambiguities - that the world is not as it seems: supernatural events are explainable; men are not the protectors they are 'meant' to be; heroines are not weak and compliant, but valiant and strong. Gothic logics as applied to Siddiqui also reveal that the world is not as it seems. In spite of having three narratives attached to her life, no one knows Siddiqui's life. Even if there is never an absolute truth, an absolute truth is lacking all the more when one tries to lift the curtain of the narratives. It may seem improbable that a $\mathrm{PhD}$ candidate at Brandeis was smuggling diamonds while also raising two children, yet there is no evidence either way. Similarly, there is no

${ }^{149}$ Cynthia Weber, 'Flying Planes Can Be Dangerous', Millennium-A Journal of International Relations 31, no. 1 (2002): 129-147, 141.

${ }^{150}$ Lee Jarvis, Times of Terror: Discourse, Temporality and the War on Terror (London: Palgrave Macmillan, 2009), 11-13.

151 Puar, 'Abu Ghraib', 523-4. 
evidence that she had a relationship with KSM, but it seems probable when she married into his family. While the US denies holding Siddiqui for five years at Bagram, potentially she is the only who knows where she was during this time. Thus, like Gothic novels, Siddiqui's life is shrouded in ambiguity that forces one to cast doubt and ask questions about the veracity of the events that surround these ambiguities: the WoT, the exceptional superiority of the US, the illegitimacy and inferiority of al Qaeda.

Aafia Siddiqui is not Rochester's wife nor is her life a Gothic novel. The WoT is as much a fiction, as a constructed war and gendered manipulation of American and Muslim identity, as the Siddiqui narratives. Yet both the WoT and the narratives have a real impact and Siddiqui is a woman whose life has been eviscerated, literally and figuratively, by the gendered neo-Orientalist hierarchical WoT. In some respects, the narratives that surround Siddiqui are not about Aafia Siddiqui. This is evident when almost none of the narratives deal with what Siddiqui has actually stated or have known conclusively to have done with the problematic exception of her statements in court that are used to demonstrate her mental frailty. Instead, her personhood represents and is representative of the WoT: "Siddiqui has become emblematic of dark American practices such as abduction, rendition, and torture" ${ }^{152}$ Therefore the narratives are more about what the various sides involved believe about themselves and about the perceived other, which provides discursive structure to the gendered hierarchy. Furthermore, I recognize the performativity embedded within this article: by naming the narratives, the narratives

${ }^{152}$ Walsh, 'Mystery'. 
are reified and replicated, as well as recast by critiquing their association with neoOrientalism.

Individual lives reflect the structures of war and the international system. The Siddiqui narratives and what has now happened to her exemplify how the gendered neo-Orientalist operations in the WoT impact an individual. Just as Gothic literature resides within a moment of transition — from religious order to modernity or a country struggling to understand where colonialism fits within its story—Siddiqui's life straddles a transition as well. Importantly, the Grey Lady narrative limits people's ability to separate themselves from the war in Afghanistan in later stages - particularly when the audience's belief that Abu Ghraib was an aberrant event is challenged. The timing of the emergence of the Grey Lady narrative is crucial. It happened in the summer of 2008 when support for the WoT and Bush's approval rating plummeted to 37\%, a marked difference from $90 \%$ just after $9 / 11 .{ }^{153}$ The Siddiqui Gothic parallels the downturn in support-it happens in the moment of transition from assuredness in American exceptionalism-as-exportedby-the-War-on-Terror towards uncertainty.

President Obama's popularity and support was in part premised on his decision to 'end' the WoT. While the discourse of the WoT is largely absent under the Obama administration, his administration's counterterrorism policies still face significant challenges. The wars in Iraq and Afghanistan may be technically over, but Obama's

${ }^{153}$ Gallup, 'Presidential Approval Ratings for George Bush', http://www.gallup.com/poll /116500/presidential-approval-ratings-george-bush.aspx (November 13, 2013). 
promise to close Guantanamo could not be practically realized. Furthermore, the discovery of torture at Bagram happened in the transition from Bush to Obama and Bagram was coined “Obama's Guantanamo," if not Abu Ghraib. Thus, the Grey Lady narrative finds fidelity in these problems. This is why Siddiqui's life and the narratives that surround it become so important: her life spans multiple tensions and multiple events.

Afghanistan as a setting encompasses both post-colonial othering/distancing as well as an uncomfortable awareness of American activity. On the one hand, these could be contrary elements, where the distance limits the reader's care for events in Afghanistan or Iraq. Othering, or the inability to conceive of different people as important or as worthy as the self, depends upon this distancing and neo-Orientalism is just one form of it. On the other hand, the human rights and anti-war communities that are a part of the Free Aafia movement built upon this distance and lack of detailed knowledge of the torture at Bagram to situate Aafia Siddiqui's innocence; the Grey Lady narrative flourishes due to the lack of concrete knowledge.

All three narratives trap Siddiqui in particular gendered and classed idealizations. Despite the opposing agendas, all three serve to diminish Siddiqui's political agency, rationality, and credibility as well as her involvement in political violence. In the first two narratives, neo-Orientalism's assumptions about male domination are still used against, and somehow, for her: first in maintaining her innocence-Siddiqui was simply a dominated Muslim woman whose husband used her to plan attacks; and second in maintaining her 
guilt — in spite of Siddiqui's advantages, she is still beholden to Muslim men, such as KSM and al Baluchi.

The neo-Orientalist assumption about Muslim irrationality is at the heart of the Grey Lady narrative. Gothic literature has long explored the connection between femininity and insanity. Femininity's relationship to emotions is threatening to rationalism. Women who engage in political violence are even more threatening - they transgress gender idealizations, violate norms on violence, and upset liberal order. ${ }^{154}$ Furthermore, Siddiqui's irrationality moves beyond femininity's weaknesses by establishing fidelity with the gendered neo-Orientalist structure of (Western) rationality and (Islamic) irrationality and of (Western) innocence and (Islamic) guilt.

The Siddiqui trial furthered this binary. Since the US was coming under criticism for trying detainees and enemy combatants in military courts, the Bush and Obama administrations moved the trials of suspected terrorists to civilian courts. Siddiqui was one of the first cases to be tried in civilian courts. During her trial President Obama announced that five Guantanamo detainees, including Siddiqui's second husband, would be tried in the same courthouse. ${ }^{155}$ The trial is emblematic "of a much larger puzzle. It is the tale...deception" related to US activities in Afghanistan and Pakistan since 2001 . $^{156}$

154 Third, 'Imprisonment', 97; author and coauthor, 2007, 37.

155 Walsh, 'Mystery'.

156 Ibid. 
Thus, the legitimacy of America's democratic practices and standards were on trial as well ${ }^{157}$ — posing doubts towards American masculinized exceptionalism.

\section{Conclusion}

With the ubiquity of gendered neo-Orientalism in media sources on everything from terrorism to migrants and Texas schoolbooks, intertextuality's utility cannot be underestimated. It serves as a method for clarifying how particular narratives, seemingly unrelated, find acceptance in a larger audience. The 'blending and crashing' of Gothic texts with media narratives helps to reveal how seemingly acceptable premises about the WoT more generally are, in actuality, problematic, if not ridiculous. Yet, to fight the WoT the US government has needed an unwavering good versus evil narrative, dependent upon gendered neo-Orientalism, inscribing it onto the citizenry's consciousness.

The WoT became a seemingly logical extension of Manifest Destiny's (patronizing) protection of 'little brown brothers' who morphed into 'little brown (veiled) sisters' ${ }^{158}$ But Manifest Destiny's protectorate vision is premised on being the sterling representative of liberal democracies. Seemingly, the more that the US tries to insist on its own unlimited masculinized exceptionalism, the more it puts those on the margins at risk. Thus, we are left to detect and uncover mysteries, working towards a clearer idea of the truth. Gothic literature teaches the reader that absolute dichotomies of

157 Ambinder, 'A Terrorist'.

158 Spivak, 'Can the Subaltern Speak?' 
masculine/feminine, just/unjust, good/evil, are not so absolute. Instead, 'real life' is unnervingly more ambiguous. 